\title{
THE IMPACT OF KNOWLEDGE MANAGEMENT PRACTICES ON THE SURVIVAL AND SUSTENANCE OF CONSTRUCTION ORGANISATIONS
}

\author{
Onyealilam Onyeagam $^{1 *}$, William Nwaki ${ }^{2}$, Bernard Obonadhuze ${ }^{3}$, Mohammed Zakariyau ${ }^{4}$ \\ ${ }^{1}$ Quantity Surveying Department, Federal Polytechnic Nasarawa, Nigeria \\ ${ }^{2}$ Building Technology Department, Delta State Polytechnic, Ozoro, Nigeria \\ ${ }^{3}$ Quantity Surveying Technology Department, Delta State Polytechnic, Ozoro, Nigeria \\ ${ }^{4}$ Quantity Surveying Department, Federal University of Technology, Owerri, Imo State, Nigeria
}

(Received: September 2020 / Revised: October 2020 / Accepted: November 2020)

\begin{abstract}
The dynamics in technological advancement and innovations in construction methods have caused construction organizations to operate in a highly competitive environment. As knowledge is an essential asset for surviving and remaining competitive in the construction industry, this study investigates the impact of knowledge management practices on the survival and sustenance of construction organizations. Construction professionals in Abuja-Nigeria were sampled using a well-structured questionnaire and multi-sampling techniques. The results of the study show that there is a low level of implementation of Knowledge Management among the construction organizations. Furthermore, it is found that the significant benefits of KM implementation are to improve the firm's competitive position, risks reduction, and better collaboration, to encourage innovation and profitability, faster problem solving, to improve project pricing, and to improve client satisfaction and patronage. It can be concluded that KM is a tactical and strategic competitive tool for surviving high competition in the construction industry. To ensure knowledge exchange between the locals and expatriates, the government should make a 'knowledge management plan' an essential part of the contract documents for pre-qualification and selection criteria.
\end{abstract}

Keywords: Competitive Advantage; Construction Industry; Construction Organization; Knowledge Management; Organizational Performance

\section{INTRODUCTION}

The construction industry's current environment is tensed due to the competitive pressure brought about by the dynamics in technological advancement and modern construction methods. Knowledge is an essential factor of production after other production factors to survive the level of competition in the construction industry including capital, land, and labour (Rašula et al., 2012). Although not all knowledge is easily transferable, an employee's exit from an organization implies that all the knowledge in his/her mind is lost, especially when they have not been converted from tacit to explicit knowledge. Construction firms' performance is linked to their survival, considering the competition in the industry. Knowledge Management (KM) is considered an essential factor to ensure increased and sustainable productivity and performance of these organizations (Santoso, 2020) since knowledge plays a crucial role in creating, developing, and retaining sustainable competitive advantage both in developed and developing countries (Koochakzadeh \& Behzadi, 2019).

*Corresponding author's email: ponyeagam@yahoo.com, Tel. +234 8068640915 DOI: https://doi.org/10.32783/csid-jid.v3i2.157 
Furthermore, knowledge has been made the most significant variable for ensuring a holistic organization and a firm's development.

$\mathrm{KM}$ is an emerging concept area in several industries, of which the construction industry is not an exception. An efficient implementation of $\mathrm{KM}$ practices in any organization helps the organization uphold a competitive advantage through knowledge resources development (Nisha, 2018). Extant literature has shown that KM impacts positively on improving organizational performance (Ben Arfi et al., 2018; S. Wang \& Noe, 2010; Z. Wang et al., 2016; Z. Wang \& Wang, 2012). As long as the staffs are with the organization, knowledge will remain the organization's property (Nonaka \& von Krogh, 2009). Thus, efforts should be made to encourage the continuous stay of such knowledge for the organization's continuity (Crossan et al., 1999; Huy, 2002). According to Call (2005), the resource-based approach is now knowledge-based.

Nigerian construction projects have been marred by constant time and cost overruns, low quality, and client dissatisfaction (Ademeso \& Windapo, 2008). Alhaji et al. (2013) submitted that the poor performance records of construction projects undertaken by the various construction firms are blamed on poor knowledge management and un-seriousness, and low interest in innovation. According to Handzic \& Durmic (2015), about $70 \%$ of failed projects were delivered behind schedule, above budget. According to Yeong Lim (2011), the insufficient knowledge creation, acquisition, storage, and transfer $\&$ from previous projects to enhance performance currently and future projects are the cause of the high rate of project failure. Excessive errors, mistakes, and reworks damage construction firms' revenue and financial capability, which threatens these organizations' future. There is usually a high level of information distortion and lost and poor record-keeping by construction organizations (Alhaji et al., 2013). To minimize time and cost overruns, rework and low quality, scope creep, and loss of profits and business opportunities, Knowledge management is advocated as a suitable strategic and tactical management tool for the survival and sustenance of construction organizations. KM concept is still at the formative stage in the Nigerian construction industry.

Based on the preceding fact about the infancy of the KM concept in Nigeria, this study was set out to assess the impact of knowledge management practices on the survival and sustenance of construction organizations by assessing KM practice's benefits. The study sorts the perception of construction professionals to meet the objective of the study. The construction professionals form the bulk of both consulting and contracting organizations' employees in the construction industry (C. E. Eze et al., 2020). The understanding of this study will be used to ensure the adoption and implementation of $\mathrm{KM}$ by construction organizations to improve project performance. According to Krogh (2002), when employees communicate and share their knowledge, experiences, lessons learned, and insights, projects' performances are improved. At the preliminary stages of projects, better results could be achieved by reusing the knowledge gained from previous projects to avoid the repetition of past mistakes. A lagging organization will also be encouraged to take-up KM practices and make them an integral part of the organization culture to serve as a critical survival tool for ensuring a comprehensive competitive position in the construction industry.

Nwaiwu and Imafidon (2017) found that telecommunication firms' survival is primarily due to the extent of knowledge management effectiveness put in practice. In Egypt, Nafei (2016) reported a statistically significant relationship between KM's dimensions and organizational success in commercial banks. Similarly, Al-Qarioti (2015) found that KM has a significant impact on organizational performance in Kuwait. In the UAE, Abusweilem \& Abualoush (2019) observed a positive relationship between the knowledge management processes and organizations' performance. Based on those previous studies, KM's implementation in the 
construction industry can be substantiated as a catalyst for sustainable growth, development, and survival.

\section{LITERATURE REVIEW}

\subsection{Knowledge and Knowledge Management}

Knowledge is known as the actions or act of knowing or having an experience or relating with experience through individual employees' participation (Rechberg \& Syed, 2014). Knowledge is a very vital resource for every organization (Suhana et al., 2020), and it becomes an asset when it is used by individuals other than the original creators of such knowledge, who are often employees in the same organization (Rechberg \& Syed, 2013, 2014; Tseng \& Fan, 2011). Organizations gain a competitive advantage significantly when knowledge sharing is entrenched.

The two major types of knowledge found in an organization and covered by knowledge management definition are tacit knowledge and explicit knowledge. Tacit knowledge is in-built, valuable, but frequently difficult to package and share knowledge (Collins, 1993). Tacit knowledge is embedded in individuals (Tywoniak, 2007), and takes the form of embedded (unconscious), embodied (physical), and embrained (cognitive). The conversion of tacit knowledge to explicit knowledge leads to knowledge creation. Meanwhile, explicit knowledge represents the type of knowledge in the form of data and information shared, transferred, and exchanged (Rechberg \& Syed, 2014).

Knowledge management $(\mathrm{KM})$ is the organizational strategic communication tool for enhancing an organization's performance and remaining above its competitors (Besanko et al., 2003). It is the asset production process of an organization that is mental or based on knowledge (Call, 2005). Nisha (2018) defined knowledge management as creating, disseminating, utilizing, and handling organizations' data and information. According to Nibusinessinfo (2020), knowledge management is the creation of value by systematically capturing and using the collective intellectual capital of a business. It involves a conscious effort to define, structure, retain, and share workers' knowledge and experiences within an organization. Knowledge management's critical objective is the acquisition, creation, integration, and usage of knowledge for an organization's optimum performance.

There are three effective knowledge management practices, including accumulating knowledge, storing knowledge, and sharing knowledge, with its primary goal to enable organizational learning and create a learning culture. According to Suhana et al. (2020) sufficient KM leads to a positive impact on an organization's output.

\subsection{Components of Knowledge Management}

Knowledge is known as the actions or act of knowing or having an experience or relating with experience through individual employees' participation (Rechberg \& Syed, 2014). Knowledge is a very vital resource for every organization (Suhana et al., 2020), and it becomes an asset when it is used by individuals other than the original creators of such knowledge, who are often employees in the same organization (Rechberg \& Syed, 2013, 2014; Tseng \& Fan, 2011). Organizations gain a competitive advantage significantly when knowledge sharing is entrenched. The key ingredients to build and grow a sustainable KM program that would improve construction organizations' competitive position and survival and sustenance in the construction industry consist of people, process, content/IT, and strategy.

The people that drive KM are organizational leadership and its employees. Therefore, the success of KM starts by getting the right people. Meanwhile, a robust organizational KM 
process assists in the management and measurement of knowledge flow. The process of which involves (1) Creation of new knowledge; (2) Identification of the knowledge critical to strategy and operations; (3) Collection of knowledge for sharing among other employees; (4) Reviewing of knowledge to appraise its impact and usefulness; (5) Knowledge sharing using documentation, collaborative activities, and informal posts; (6) Utilization of a pull and push mechanism to access knowledge; (7) Utilization of knowledge to make an informed decision towards solving problems faster. On the other hand, knowledge content and IT tools are needed to make the right knowledge available to the right people. It involves the development of templates and videos and unstructured project documentation. The IT components make the creation of the content easy and improve accessibility and reuse. Furthermore, an effective KM practice requires a clear and documented business-relevant strategy. It means that having the latest technology tools and an intelligent and smart KM team without a strategy means KM will not be sufficient.

The four major components of KM practices are linked because with the right people; valuable content will be developed and stored for reuse using available IT facilities. The created knowledge is made following the set processes. Above all, the people, process, and content/IT are backed up and driven by a clear and adequately documented organizational strategy (See Figure 1).

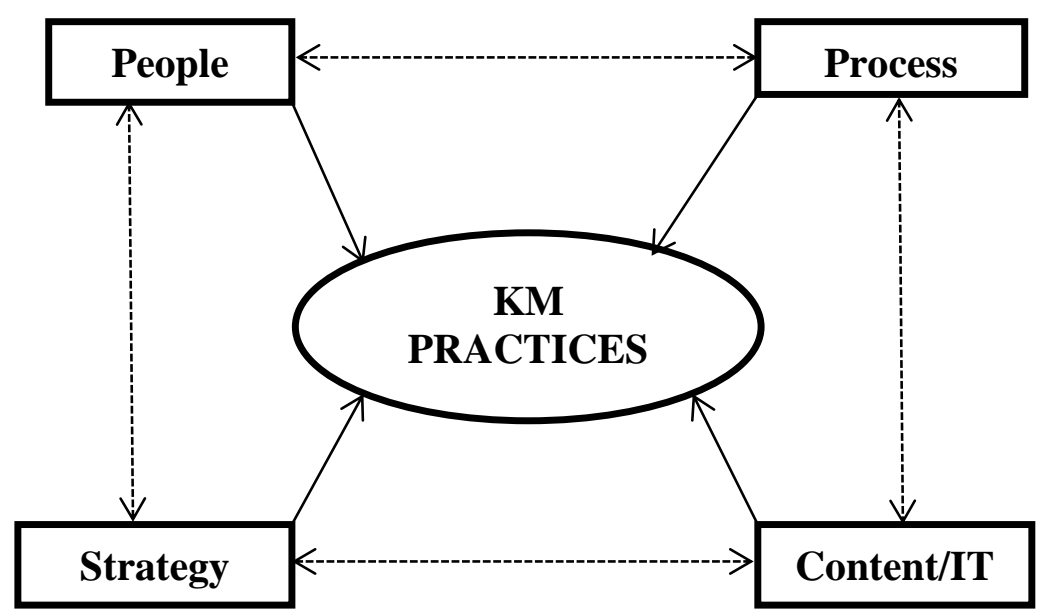

Figure 1. Ingredient of knowledge management practices

\subsection{Components of Knowledge Management}

KM practices can be broadly grouped into Tactical and Strategic KM Practices (Knowledge Management Tools, 2018). The processes and practices support strong organizational management knowledge management culture, people, and information technology facilities. The essence is to gain a more substantial competitive advantage over competitors for the survival and sustenance of an organization, especially in a highly competitive industry like construction. Tactical KM practices encompass knowledge sharing, knowledge reuse, knowledge creation, and knowledge acquisition.

Strategic KM practices involve processes supported by the organizational structures, organizational cultural changes, knowledge retention, core competencies, the external network, and the company's knowledge management system. If these practices are correctly implemented and control measures put in place, it will improve investment that will encourage efficiency, innovation, competitive advantage, and learning (Knowledge Management Tools, 2018). An efficient and innovative organization will experience increased revenue generation and profit maximization, better market share, and strong competitive strength. These would translate to 
the organization's continuous survival and sustenance in the industry in which its operations (see Figure 2). Therefore, it can be said that Knowledge Management leads to sustainable competitive advantage and healthy organizational advancement.

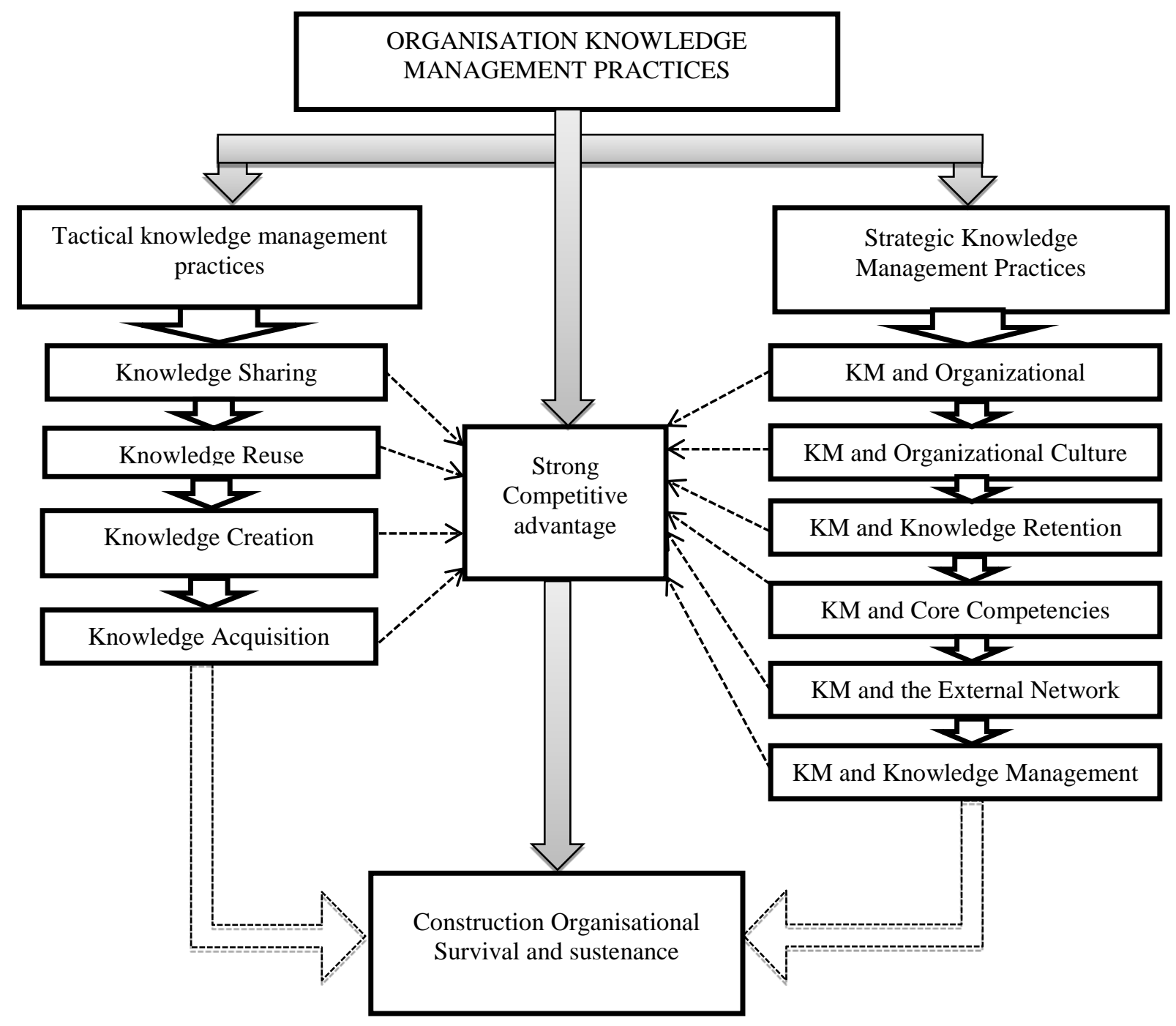

Figure 2. Knowledge management practices for survival and sustenance of organisation

\subsection{Impact of KM Practices on Construction Organizations' Performance}

KM practices can be broadly grouped into Tactical and Strategic KM Practices (Knowledge Management Tools, 2018). The processes and practices support strong organizational management knowledge management culture, people, and information technology facilities. The essence is to gain a more substantial competitive advantage over competitors for the survival and sustenance of an organization, especially in a highly competitive industry like construction. Tactical KM practices encompass The construction industry is confronted with strong competitive forces in its quest for survival and sustenance like every other economic sector (E. Eze, Idiake, et al., 2018). Despite the growing pressure on construction organizations' need to embrace effective knowledge management practices, existing studies have shown shallow acceptance and adoption of the concept. One of the marketing strategies often adopted by construction firms is maintaining a strong pool of experienced and knowledgeable professionals. It has been found to boost a company's competitive image and performance (E. Eze, Sofolahan, et al., 2018). Valmohammadi \& Ahmadi (2015) found that KM practices have a positive, meaningful, but weak impact on overall organizational performance. However, the 
impact is more on the growth and learning dimension. In an empirical study, Payal et al. (2019) found a significant positive link between KM strategy, enablers and processes, and organizational performance.

Many benefits can be gained from the utilization of knowledge transfer (Abu Bakar et al., 2016). According to Osabutey and Jin (2016), firms' efficiency will improve if the supportive KM system is entrenched in their operations and functioning. Oke et al. (2013) submitted that effective utilization of $\mathrm{KM}$ practices influences organizational performance. It further stated that many areas of the construction projects undertaken by organizations would improve. However, much of the improvement will be seen in improved communication skills, training benefits of the new employee, job analysis and specification, improvement in productivity, and Increased customer satisfaction.

Abu Bakar et al. (2016) stated that once the management of a construction organization prioritizes the importance of knowledge transfer in achieving its set organizational goals, its workforce will consciously channel its resource towards activities that encourage good knowledge transfer practice and increased productivity. Furthermore, Khalfan et al. (2010) reported that some of the benefits of the knowledge transfer in supply chain management include a community of practice, facilitating cooperation, continuous work, and future work opportunities with the same client for a longer time. Another benefits of KM to an organization are that it helps achieve company growth performance, brings about innovation and creativity, improves company productivity, helps improve company revenue drive and profitability, and improves firms' competitive advantages, reduces the time and cost of solving problems, improves the quality of the solutions, minimizes the need to consult past projects (Yusof \& Bakar, 2012). KM brings benefits to organizational efficiency as it improves organizational efficiency, reduces training cost, improves project performance, reduces risks of uncertainty, improves sharing of specialist expertise, provides better and faster decision making (Alhaji et al., 2013; Nibusinessinfo, 2020; Ruuska \& Vartiainen, 2005; Tseng \& Fan, 2011; van Donk \& Riezebos, 2005; Von Krogh, 2002).

Morever, Ko \& Alan (2011) stated that KM's application among middle and front-line workers would influence communication and technical skills. It was further revealed that job knowledge and skills are essential in making excellent and reliable decisions. Budgetary control, contract management, material planning, workforce planning and control, and negotiating with other involved parties were essential areas that knowledge management could improve. The study also revealed that KM could improve individual performance, which sums up to improved productivity and performance of the organization and the industry.

However, reaping the full benefits of KM practices suffers from some drawbacks. The construction industry does not have a strong record of valuing its employees and their individual and collective contributions (Yusof \& Bakar, 2012). It, therefore, makes it more difficult to share knowledge. Tacit knowledge tends to be regarded as personal property rather than organizational property. Hierarchical organizational structures and multi-disciplinary teams also make it more difficult to share knowledge. According to Leal et al. (2017), the introduction of new management structures to deal effectively with knowledge management may be viewed with suspicion. Likewise, radical changes in work practices are not desirable. Any task that is seen as requiring more effort will not be widely accepted. KM will have to become an integral part of the way individuals work to succeed. It is based on some of the challenges of implementing comprehensive KM that this study assessed KM practice's benefits on the survival and sustenance of construction organizations. 


\section{METHODOLOGY}

This study sorts the perception of construction professionals in Abuja, Nigeria to answer its objective, including Architects, Engineers (civil\& Services), Builders, and Quantity Surveyors with at least five years of experience, have good knowledge of the subject under consideration and are actively involved in an on-going construction project. These set criteria would help reduce response bias and improve the data collected. Abuja was chosen for its uniqueness in infrastructural development and its housing provisions to meet the growing population's physiological needs. It houses many professional firms, professional organizations offices, and construction companies. It is also the headquarters for most government agencies involved in infrastructural provisions. This study adopted a quantitative research approach using a questionnaire as the primary instrument for data collection, examining the relationship between realities and comparing findings with existing theories or previous research reports (Creswell \& Creswell, 2005; Culka, 2018). The questionnaire was used because it covers a broader audience, commonly used in social research instruments (Blaxter et al., 2001; Tan, 2011).

A non-probabilistic convenience and snowball sampling methods were utilized in the gathering of the data using a questionnaire. Snowball sampling is dependent on referrals, and the techniques assume a link exists among a homogenous population. The researchers to the target participants using convenient sampling initially administered the questionnaire. Electronic means were later used in the administration of the questionnaire using snowball sampling techniques. It was done to increase the response rate and feedback system. These include short sampling time, increase sample size, and the need to sample participants that met the set criteria (Etikan, 2016) at their convenience and availability. A closed-ended questionnaire type was used and used a 5-point Likert scale in which 1 is the lowest rating, and 5 is the highest rating.

The questionnaire used was designed into four sections. The first section gathered data on the respondents' background information. The second section gathered information on the level of agreement on KM practices' impact on construction firms' competitive advantage. The last section asked questions on the level of agreement on KM's impact on the survival and sustenance of construction organizations, using KM practices' benefits. Twenty-two benefits of $\mathrm{KM}$ were selected from the literature.

After eleven weeks survey period, a total of 172 responses were received. It comprised of 88 hard copies and 84 electronic questionnaires. The analyses of the gathered data started by first establishing the reliability of the research instrument. The questionnaire reliability test was carried out using Cronbach's alpha test, which resulted in an alpha value of 0.823 for the assessed variables. It showed that the research instrument is reliable as opined by (Moser, 2017; Tavakol \& Dennick, 2011) since the alpha value is more significant than 0.70 . Frequency, percentile, and radar were used to assess the data gathered on the questionnaire's first and second sections. While factor analysis (FA) using principal component analysis (PCA) with varimax rotation as the extraction method was used to analyze the data gathered on KM's impact on a construction organization's survival. Factor analysis was used to group the 22 identified variables into a more manageable proportion and size for ease of interpretation. The FA was performed using the statistical package for social science.

\section{RESULTS AND DISCUSSION}

\subsection{Respondents' Background Information}

The respondents' background information in Table 1 revealed that $63.95 \%$ of them are private construction organizations employees, while the rest, 36.05\%, are employees of public organizations. Regarding their professions, 37.21\% are Engineers, 33.72\% are Quantity Surveyors, and the Architects and the rest $14.53 \%$ are Builders. The average respondents' years 
of experience are 14.31 years, with a median and modal class of $11-15 y$ years. $41.86 \%$ of the respondents' hold a bachelor's degree (BSc/B. Tech), 27.33\% hold a master's degree (M.Sc/M.Tech), $16.86 \%$ hold a higher national diploma (HND), $11.63 \%$ had a postgraduate diploma (PGD), and the rest $2.33 \%$ hold with a doctorate (Ph.D.). This section showed that the participants are experienced, academically, and professionally qualified and have the requisite knowledge to make a meaningful contribution to this study's objective.

Table 1 Respondents' background information

\begin{tabular}{llcc}
\hline Category & Classification & Frequency & Percentage \\
\hline Ownership of the organization & Public & 62 & $36.05 \%$ \\
& Private & 110 & $63.95 \%$ \\
\hline Profession of respondents & Architects & 25 & $14.53 \%$ \\
& Builders & 25 & $14.53 \%$ \\
& Engineers & 64 & $37.21 \%$ \\
& Quantity Surveyors & 58 & $33.72 \%$ \\
\hline Years of experience & 5 - 10years & 35 & $20.35 \%$ \\
& 11-15 years & 65 & $37.79 \%$ \\
& 16-20 years & 43 & $25.00 \%$ \\
& Above 20 & 29 & $16.86 \%$ \\
\hline Highest academic qualification & HND & 29 & $16.86 \%$ \\
& PGD & 20 & $11.63 \%$ \\
& BSc/B.Tech & 72 & $41.86 \%$ \\
& M.Sc/M.Tech & 47 & $27.33 \%$ \\
& PhD & 4 & $2.33 \%$ \\
\hline Professional status & Corporate member & 153 & $88.95 \%$ \\
& Probationer member & 19 & $11.05 \%$ \\
\hline
\end{tabular}

\subsection{Level of Implementation of KM Practices in the Current Organizations}

The respondents' background information in Table 1 revealed that $63.95 \%$ of them are private construction organizations employees, while the rest, 36.05\%, are employees of public organizations. Regarding their professions, the result shows that $19.77 \%$ of the respondents stated that the KM implementation level in their organizations is very low, followed by $27.91 \%$ stated the low level of KM implementation. A moderate level of the application was indicated by $23.84 \%$ of the respondents. A high level and a very high level of KM implementation were indicated by $16.28 \%$ and $12.21 \%$ of the respondents, respectively (Figure 3 ). These findings show that the implementation level of KM practices is still generally low. It further shows that $\mathrm{KM}$ is still in the infancy in Nigerian and, by extension, other developing countries of Africa and beyond. KM implementation is still being hindered by certain factors which affect the operation and functioning of construction organization in Nigeria. A larger proportion of the construction organizations in Nigeria are SMEs and lack proper structures to encourage Knowledge management. This result further reveals why some organizations are doing well while others are not and why some companies die off within a short time of establishment. Thus, KM is one of the keys to organizational survival and achieving strategic competitive superiority. 


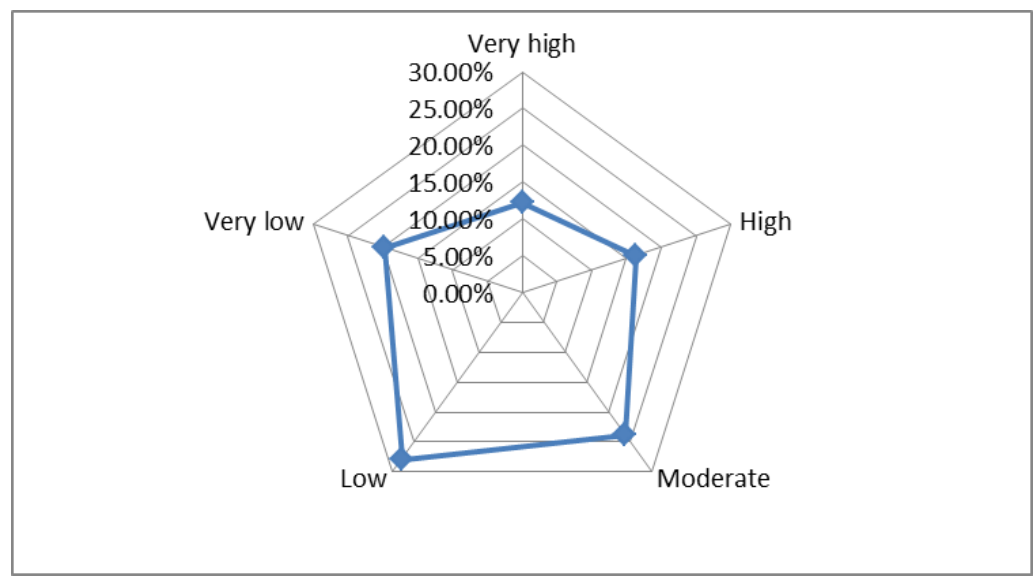

Figure 3. Level of implementation of KM in the organisation

\subsection{Benefits of KM Practices to Construction Organizations}

The suitability and factorability of the gathered data for factor analysis were first carried out. The sample size, number of variables, commonalities, Kaiser-Meyer-Olkin (KMO) measure of sampling adequacy, and Bartlett's test of sphericity were checked for adequacy and suitability, and factorability before carrying out the factor analysis. Regarding the number of variables, there is yet to be an agreement among researchers on what number of variables should be suitable for FA, making the 22 variables adequate. Similarly, based on the suggestions of Pallant (2013), Hair et al. (2010), Bryant \& Yarnold (1995), and Tabachnick \& Fidell (2007), the sample size of 172 is adequate for FA. Furthermore, as long as the communalities are high, model error is low and the number of expected factors is relatively small (Preacher \& MacCallum, 2002).

E. Eze, Idiake, et al. (2018) submit that variables with communalities figure of $\geq 0.5$ fits well in the construct with other variables. The average communalities value of the tested variable is 0.647 , with maximum and minimum values of 0.963 and 0.500 , respectively. The KMO value of 0.763 was obtained, and this is higher than the cut-off score of 0.50 suggested by (Field, 2005; Hair et al., 2010). Similarly, for the Bartlett test carried out, a chi-square value of 2061.678, $\mathrm{df}=231$, and $\mathrm{p}$-value of 0.000 were obtained. It supports Tabachnick and Fidell (2007) and Field (2005) regarding Bartlett's test's P-value. With the result of Bartlett's test of sphericity, it can be concluded that there is a patterned relationship between the variables (E. Eze, Idiake, et al., 2018). The data gathered were concluded to be suitable and adequate for factor analysis, based on the initial tests. Following the factorability confirmation, factor analysis was consequently executed.

\subsubsection{Principal Component Analysis (PCA) and Factor Extraction}

Factor analysis was carried out using principal component analysis (PCA) with varimax rotation as the extraction method. Based on the PCA and varimax rotation, six factors were extracted and accounted for about $62.44 \%$ of the total cumulative variance. These were based on the factors with eigenvalues $\geq 1$. The final statistics of PCA and varimax rotation, which accounted for $62.44 \%$, fulfilled the propositions of (Cole \& Sterner, 2000; Pallant, 2013) concerning the extracted factors which are expected to be greater than $50 \%$; and the $60 \%$ proposed by Hair et al. (2010). In addition to the PCA statistics, only factors with a factor loading of $\geq 0.50$ were retained in line with Spector's statement (2011) as shown in Table 2.

A critical observation of the scree plot (Figure 4) shows that a break occurred after the sixth factor (at the 7th factor). It shows that factors with Eigenvalues more significant than 1 occur before the 7th factor when the break (slope) occurred. According to Costello \& Osborne (2005), 
the point where the break occurs should not be included. Therefore, only the six components that occurred before the break were suitable for extraction and were subsequently retained. They capture much of the variance than the remaining components (E. Eze, Idiake, et al., 2018). The PCA statistics and scree plot, therefore, justify the six factors extracted.

Table 2 Benefits of KM practices to construction organizations

\begin{tabular}{|c|c|c|c|c|c|c|}
\hline & \multicolumn{6}{|c|}{ Component } \\
\hline & 1 & 2 & 3 & 4 & 5 & 6 \\
\hline Improves firms' competitive advantages & 0.973 & & & & & \\
\hline Improvement in productivity & 0.973 & & & & & \\
\hline Reduction in errors and mistakes of past projects & 0.965 & & & & & \\
\hline The efficiency of firms will improve & 0.956 & & & & & \\
\hline leads to organizational growth & 0.863 & & & & & \\
\hline reduce risks of uncertainty & & 0.693 & & & & \\
\hline sharing of specialist expertise & & 0.665 & & & & \\
\hline Prevent reinvention of the wheel & & 0.587 & & & & \\
\hline improvement in communication skills & & 0.573 & & & & \\
\hline innovation and creativity & & & 0.702 & & & \\
\hline improve company revenue drive and profitability & & & 0.629 & & & \\
\hline improves project performance & & & 0.540 & & & \\
\hline it reduces training cost & & & 0.507 & & & \\
\hline reducing the time and cost of solving problems & & & & 0.715 & & \\
\hline improving the quality of the solutions & & & & 0.546 & & \\
\hline training benefits of new employee & & & & 0.517 & & \\
\hline job analysis and specification & & & & & 0.732 & \\
\hline better and faster decision making & & & & & 0.632 & \\
\hline minimizing the need to consult past projects & & & & & 0.528 & \\
\hline Opportunities for repeat patronage & & & & & & 0.675 \\
\hline Increased customer satisfaction & & & & & & 0.534 \\
\hline Eigenvalues & 5.23 & 2.86 & 1.80 & 1.51 & 1.24 & 1.10 \\
\hline$\%$ of Variance & 23.76 & 13.02 & 8.18 & 6.84 & 5.62 & 5.02 \\
\hline Cumulative $\%$ of the variance & 23.76 & 36.78 & 44.96 & 51.80 & 57.42 & 62.44 \\
\hline number of extracted variables & 5 & 4 & 4 & 3 & 3 & 2 \\
\hline
\end{tabular}

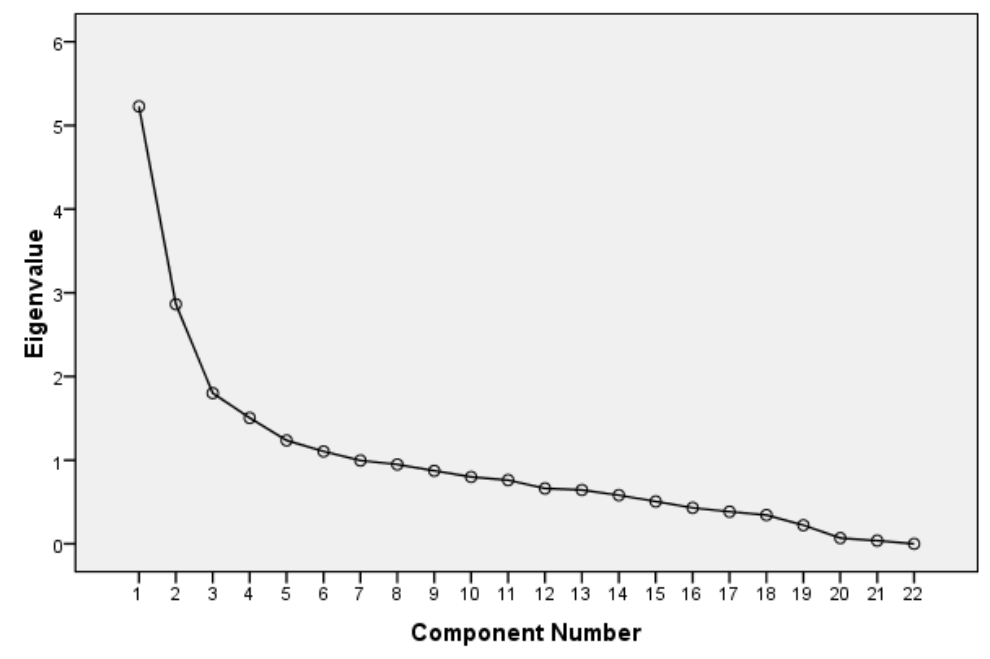

Figure 4. Screen plot of factor extraction

\subsubsection{Naming of cluster and discussion of extracted factors}

The naming of the FA cluster was influenced by the components' latent characteristics loaded under the components. Though it was difficult to give a proper name, consideration was given 
to the variable(s) with the highest factor loading (FL) among the variables that loaded under a component.

Results in Table 2 show that five items loaded strongly under the first component accounted for about $23.76 \%$ of the total variance of the retained variables, which includes: improves firms' competitive advantages $(\mathrm{FL}=0.973)$, improvement in productivity $(\mathrm{FL}=0.973)$, reduction in errors and mistakes of past projects $(\mathrm{FL}=0.965)$, the efficiency of firms will improve $(\mathrm{FL}=0.956)$ and leads to organizational growth $(\mathrm{FL}=0.863)$. This component was named 'Improve the firm's competitive position' after examining the variables' characteristics. KM practices, when effectively implemented, could influence the overall productivity of an organization. This is because the previous mistake, errors, and shortcomings are not repeated, thus leading to better efficiency of the workforce and the organization. KM improves a firm's efficiency, helps achieve company growth performance, guarantees increased and sustainable productivity and performance of organizations (Ko \& Dennis, 2011; Osabutey \& Jin, 2016; Suhana et al., 2020; Yusof \& Bakar, 2012), hence improve its competitive advantages to survive in the competitive construction industry.

The second component was named 'Risks reduction and better collaboration' following a cursory examination of the latent characteristics of the strongly loaded items unto it. This component four items and accounted for $13.02 \%$ of the total variance explained. The items that loaded unto this component include: reduce risks of uncertainty $(\mathrm{FL}=0.693)$, sharing of specialist expertise $(\mathrm{FL}=0.665)$, Prevent reinvention of the wheel $(\mathrm{FL}=0.587)$, and improvement in communication skills $(\mathrm{FL}=0.573) . \quad \mathrm{KM}$ practices encourage collaborations and communication between organizations. There is the minimization of risks and uncertainty due to the avoidance of delays in reinventing the wheels. It encourages the sharing of expertise experiences, which forms the bulk of tacit knowledge. This knowledge is created and converted to explicit knowledge for record purpose and reused in times of need for better performance and risk reduction. During the collaboration, the company remains afloat in a competitive industry like the construction industry. KM reduces risks of uncertainty (Alhaji et al., 2013) by facilitating cooperation, collaboration, a community of practice, and continuous work and opportunities for future work with the same client for a longer time (Khalfan et al., 2010). KM's application among middle and front-line workers will influence communication and technical skills (Ko \& Dennis, 2011).

The third component, named 'Encourages innovation and profitability', accounted for $8.18 \%$ of the total variance explained and comprised four items. The items included under these components are innovation and creativity $(\mathrm{FL}=0.702)$, improve company revenue drive and profitability $(\mathrm{FL}=0.629)$, improves project performance $(\mathrm{FL}=0.540)$, and reduce training cost $(\mathrm{FL}=0.507)$. The construction industry is dominated by SMEs that face many business challenges. One of which is the lack of innovation that has been described as one of the killers of most construction SMEs in developing countries, particularly in Africa. Innovation and creativity are among the skills expected of employees for the growth and development of their employers. KM encourages innovation in a company, increasing its productivity, performance, revenue, and profitability, supporting positive growth, survival, and sustenance of construction organizations.

The fourth component, 'Faster problem solving', has three items accounting for about $6.84 \%$ of the total variance explained. These items include reducing the time and cost of solving problems $(\mathrm{FL}=0.715)$, improving the quality of the solutions $(\mathrm{FL}=0.546)$, and training benefits of new employees $(\mathrm{FL}=0.517)$. $\mathrm{KM}$ practices enable construction firms to do a postconstruction review where data related to lessons learned are mined and recorded for reuse. This helps improve the quality of solutions and decisions for future projects and reduces the 
cost of training new employees and engaging external experts. This finding is in line with previous studies' results (Alhaji et al., 2013; Chou et al., 2012; Ruuska \& Vartiainen, 2005; van Donk \& Riezebos, 2005; Von Krogh, 2002).

Three factors loaded under the fifth component named 'improves project pricing' and account for $5.62 \%$ of the total variance explained. The three items are job analysis and specification $(\mathrm{FL}=0.732)$, better and faster decision making $(\mathrm{FL}=0.632)$, and minimizing the need to consult past projects $(\mathrm{FL}=0.528)$.

$\mathrm{KM}$ decides on current projects quickly and faster by providing historical records of previous construction contracts and project documents where references can be made with little effort and less stress. Proposed projects can be appropriately evaluated and analyzed and then priced adequately with the best rates possible to gain a better advantage during tender evaluation. When new tenders are adequately priced, there is the possibility of the construction organization to be awarded the project. It is one of the core impacts of knowledge management on organizations. Reasonable rates of work items of construction projects give a contractor an edge over its competitors and improve its chance of being awarded more jobs. This improves the survival and sustenance of construction contractors.

This sixth component, 'improve client satisfaction and patronage', contains two items and accounts for $5.02 \%$ of the total variance explained and the $62.44 \%$ cumulative variance of the extracted factors. The items are opportunities for repeat patronage $(\mathrm{FL}=0.675)$ and increased customer satisfaction $(\mathrm{FL}=0.534)$. A cursory examination of these items' characteristics shows they are closely related to the need to secure repeated jobs and client satisfaction. KM practices enable construction organizations to continue being in business as a result of sustainable client satisfaction. Clients are tended to go back to contractors that satisfied them in terms of cost, time, quality, and other performance requirements of their previous construction projects. An organization that continuously satisfies its customers will experience sustainable patronage, which would increase revenue and profitability, growth, and would be on a better advantage over its competitors. Thus, they would experience a sustainable advantage and survival in the industry.

\section{CONCLUSION AND RECOMMENDATIONS}

This study assessed the impact of knowledge management (KM) practices on construction organizations' survival and sustenance. The study gathered information from construction professionals in both public and private organizations in Abuja, Nigeria. Utilizing convenient and snowball sampling techniques and questionnaire surveys, the study determined the significant clusters of factors of benefits of KM to the survival and sustenance of construction organizations in Nigeria.

The study concludes that there is a low level of knowledge management among construction organizations in the construction industry. However, the significant benefits of KM implementation that impact construction organizations' survival and sustenance include improving the firm's competitive level, risks reduction and better collaboration, encouraging innovation and profitability, faster problem solving, improving project pricing, and improving client satisfaction and patronage. It confirms that KM is a tactical and strategic tool for gaining a competitive advantage for the survival of construction firms in a highly competitive industry like the construction industry.

Based on the findings, construction organizations are recommended to encourage KM practices across all the supply and construction value chains to continue thriving in the industry. However, encouragement and financial support from the government are needed for these 
organizations to secure the necessary ICT facilities for implementing KM. This study adds to the available body of knowledge on KM practices in the construction industry. The study is expected to assist managers/owners of construction organizations to make an informed decision regarding investing in KM. Furthermore, the outcome of this study can be utilized by construction organizations to guide their operations, especially in areas of retaining the best knowledge assets and developing employees. Its geographical boundary and sample size limit this study; therefore, care should be exercised to generalize the findings. However, a similar study should be carried out in other parts of the country to be compared. An investigation of the impact of industry 4.0 on $\mathrm{KM}$ and organizational performance and a quantitative study ascertaining the relationship between $\mathrm{KM}$ and the rework management and project quality improvement are required for further research.

\section{REFERENCES}

Abu Bakar, A. H., Yusof, M. N., Tufail, M. A., \& Virgiyanti, W. (2016). Effect of knowledge management on growth performance in construction industry. Management Decision, 54(3), 735-749. https://doi.org/10.1108/MD-01-2015-0006

Abusweilem, M. A., \& Abualoush, S. (2019). The impact of knowledge management process and business intelligence on organizational performance. Management Science Letters, 9(12), 2143-2156. https://doi.org/10.5267/j.msl.2019.6.020

Ademeso, O. S., \& Windapo, A. O. (2008). Relationship between material management approach and scheduled project completion time. COBRA 2008 - Construction and Building Research Conference of the Royal Institution of Chartered Surveyors.

Al-Qarioti, M. Q. A. (2015). The Impact of Knowledge Management on Organizational Performance: An Empirical Study of Kuwait University. Eurasian Journal of Business and Management, 3(4), 36-54. https://doi.org/10.15604/ejbm.2015.03.04.004

Alhaji, K. M., Amiruddin, R., \& Abdullah, F. (2013). Knowledge Sharing Practices in Construction Organisation in Nigeria. International Journal of Engineering Research \& Technology (IJERT), 2(1), 1-10.

Ben Arfi, W., Hikkerova, L., \& Sahut, J. M. (2018). External knowledge sources, green innovation and performance. Technological Forecasting and Social Change, 129, 210 220. https://doi.org/10.1016/j.techfore.2017.09.017

Besanko, D., Dranove, D., \& Shanley, M. (2003). Competitors and competition. In Economics of Strategy (p. 36). https://padlet.com/carodriguezro/ng9v6arydiqnw183

Blaxter, L., Hughes, C., \& Tight, M. (2001). How to Research. Open University Press, London. https://www.amazon.com/How-Research-Open-Study-Skills/dp/033523867X

Bryant, F. B., \& Yarnold, P. R. (1995). Principal-components Analysis and Exploratory and Confirmatory Factor Analysis. In L. G. Grimm \& P. R. Yarnold (Eds.). In Reading and understanding multivariate statistics.

Call, D. (2005). Knowledge management - Not rocket science. In Journal of Knowledge Management (Vol. 9, Issue 2, pp. 19-30). https://doi.org/10.1108/13673270510590191

Chou, J. S., Ping Tserng, H., Lin, C., \& Yeh, C. P. (2012). Critical factors and risk allocation for PPP policy: Comparison between HSR and general infrastructure projects. Transport Policy, 22, 36-48. https://doi.org/10.1016/j.tranpol.2012.05.009

Cole, R. J., \& Sterner, E. (2000). Reconciling theory and practice of life-cycle costing. Building Research and Information, 28(5-6), 368-375. https://doi.org/10.1080/096132100418519

Collins, H. (1993). The Structure of Knowledge. Social Research, 60(1), 95-116. http://www.jstor.org/stable/40970729

Costello, A. B., \& Osborne, J. W. (2005). Best practices in exploratory factor analysis: Four recommendations for getting the most from your analysis. Practical Assessment, Research and Evaluation, 10(7). 
Creswell, J. W., \& Creswell, J. D. (2005). Mixed methods research: developments, debates, and dilemma. In Research in Organizations: Foundations and Methods of Inquiry.

Crossan, M. M., Lane, H. W., \& White, R. E. (1999). An Organizational Learning Framework: From Intuition to Institution. The Academy of Management Review, 24(3), 522. https://doi.org/10.2307/259140

Culka, M. (2018). Quantitative scenario design with Bayesian model averaging: constructing consistent scenarios for quantitative models exemplified for energy economics. Energy, Sustainability and Society, 8(1). https://doi.org/10.1186/s13705-018-0162-3

Etikan, I. (2016). Comparison of Convenience Sampling and Purposive Sampling. American Journal of Theoretical and Applied Statistics, 5(1), 1. https://doi.org/10.11648/j.ajtas.20160501.11

Eze, C. E., Awodele, I. A., Adegboyega, A. A., Onyeagam, O. P., \& Guto, J. (2020). Assessment of the triggers of inefficient materials management practices by construction SMEs in Nigeria. International Journal of Real Estate Studies, 14(1), 38-56.

Eze, E., Idiake, J. E., \& Ganiyu, B. O. (2018). Analysis of Rework Risk Triggers in the Nigerian Construction Industry. Organization, Technology and Management in Construction: An International Journal. https://doi.org/10.2478/otmcj-2018-0008

Eze, E., Sofolahan, O., Onyeagam, O. P., \& Muhammed, U. (2018). Construction professionals' perception of the marketing strategies employed by construction firms in Abuja, Nigeria. Journal of Construction Project Management and Innovation, 8(2), 19051925.

Field, A. (2005). Discovering Statistics Using SPSS (Introducing Statistical Methods S.). In Methods (Vol. 3rd). SAGE Publications. http://www.amazon.com/dp/0761944524

Hair, J. F., Black, W. C., Babin, B. J., \& Anderson, R. E. (2010). Multivariate Data Analysis. In Vectors. https://doi.org/10.1016/j.ijpharm.2011.02.019

Handzic, M., \& Durmic, N. (2015). Knowledge Management, Intellectual Capital and Project Management: Connecting the Dots. The Electronic Journal of Knowledge Management, $13(1), 51-61$.

Huy, Q. N. (2002). Emotional balancing of organizational continuity and radical change: The contribution of middle managers. Administrative Science Quarterly, 47(1), 31-69. https://doi.org/10.2307/3094890

Khalfan, M. A., Kashyap, M., Li, X., \& Abbott, C. (2010). Knowledge management in construction supply chain integration. International Journal of Networking and Virtual Organisations, 7(2-3), 207-221. https://doi.org/10.1504/ijnvo.2010.031218

Knowledge Management Tools. (2018). Summary: Knowledge Management Best Practices. http://www.knowledge-management-tools.net/KM-best-practices.html

Ko, D. G., \& Dennis, A. R. (2011). Profiting from knowledge management: The impact of time and experience. Information Systems Research, 22(1), 134-152. https://doi.org/10.1287/isre.1090.0247

Koochakzadeh, R. S., \& Behzadi, S. (2019). The role of KM tactical factors in supply chain management for gaining competitive advantage. International Journal of Supply Chain Management, 8(2), 836-851.

Leal, C., Cunha, S., \& Couto, I. (2017). Knowledge sharing at the construction sector Facilitators and inhibitors. Procedia Computer Science, 121, 998-1005. https://doi.org/10.1016/j.procs.2017.11.129

Moser, C. A. (2017). Survey Methods in Social Investigation. In Survey Methods in Social Investigation. Routledge. https://doi.org/10.4324/9781315241999

Nafei, W. A. (2016). Knowledge Management: The Key to Organizational Success. In International Journal of Case Studies (Vol. 5, Issues 2016-08). http://www.casestudiesjournal.com/ 
Nibusinessinfo. (2020). Knowledge management and business growth: Advantages and disadvantages of knowledge management. https://www.nibusinessinfo.co.uk/content/advantages-and-disadvantages-knowledgemanagement

Nisha, R. (2018). Knowledge management and recovery processes using IT: An approach towards Data Mining. International Journal of Supply Chain Management, 7(6), 57-60.

Nonaka, I., \& von Krogh, G. (2009). Tacit knowledge and knowledge conversion: Controversy and advancement in organizational knowledge creation theory. Organization Science, 20(3), 635-652. https://doi.org/10.1287/orsc.1080.0412

Nwaiwu, J. C., \& Imafidon, H. C. (2017). Knowledge management and organisational survival: a study of telecommunication industry in Port Harcourt, Nigeria. International Journal of Advanced Academic Research, 3(7), 40-53.

Oke, A. E., Ogunsemi, D. R., \& Adeeko, O. C. (2013). Assessment of knowledge management among construction professionals in Nigeria. Journal of Construction Project Management and Innovation. http://reference.sabinet.co.za/sa_epublication_article/jcpmi_v3_n2_a4

Osabutey, E. L. C., \& Jin, Z. (2016). Factors influencing technology and knowledge transfer: Configurational recipes for Sub-Saharan Africa. Journal of Business Research, 69(11), 5390-5395. https://doi.org/10.1016/j.jbusres.2016.04.143

Pallant, J. (2013). A step-by-step guide to data analysis using SPSS version 15. In Open University Press, Maidenhead.

Payal, R., Ahmed, S., \& Debnath, R. M. (2019). Impact of knowledge management on organizational performance: An application of structural equation modeling. VINE Journal of Information and Knowledge Management Systems, 49(4), 510-530. https://doi.org/10.1108/VJIKMS-07-2018-0063

Preacher, K. J., \& MacCallum, R. C. (2002). Exploratory factor analysis in behavior genetics research: Factor recovery with small sample sizes. Behavior Genetics, 32(2), 153-161. https://doi.org/10.1023/A:1015210025234

Rašula, J., VUkšić, vesna B., \& ŠteMBeRGeR, M. indiHar. (2012). The impact of knowledge management on organisational performance. In Economic and Business Review (Vol. 14, Issue 2). https://www.researchgate.net/publication/265401753

Rechberg, I., \& Syed, J. (2013). Ethical issues in knowledge management: Conflict of knowledge ownership. In Journal of Knowledge Management (Vol. 17, Issue 6, pp. 828847). https://doi.org/10.1108/JKM-06-2013-0232

Rechberg, I., \& Syed, J. (2014). Knowledge management practices and the focus on the individual. International Journal of Knowledge Management, 10(1), 26-42. https://doi.org/10.4018/ijkm.2014010102

Ruuska, I., \& Vartiainen, M. (2005). Characteristics of knowledge sharing communities in project organizations. International Journal of Project Management, 23(5 SPEC. ISS.), 374-379. https://doi.org/10.1016/j.ijproman.2005.01.003

Santoso, A. (2020). Knowledge management, supply chain marketing implementation and marketing capabilities and tourism industry performance in Indonesia. International Journal of Supply Chain Management, 9(3), 1003-1012.

Spector, P. (2011). Summated Rating Scale Construction. In Summated Rating Scale Construction. Sage Publications. https://doi.org/10.4135/9781412986038

Suhana, S., Suharnomo, S., Mas'ud, F., Mansyur, A., Febrianto, B., \& Santoso, I. H. (2020). Investigating the role of the knowledge sharing and innovative behavior in supply chain management. International Journal of Supply Chain Management, 9(3), 871-880.

Tabachnick, B. G., \& Fidell, L. S. (2007). Using Multivariate Statistics 5. In Boston: Pearson Allyn and Bacon. Pearson.

Tan, W. (2011). Practical Research Methods. Pearson Custom, Singapore. 
https://www.amazon.com/Practical-Research-Methods-Third-Revised/dp/981068021X

Tavakol, M., \& Dennick, R. (2011). Making sense of Cronbach's alpha. In International journal of medical education (Vol. 2, pp. 53-55). https://doi.org/10.5116/ijme.4dfb.8dfd

Tseng, F. C., \& Fan, Y. J. (2011). Exploring the Influence of Organizational Ethical Climate on Knowledge Management. Journal of Business Ethics, 101(2), 325-342. https://doi.org/10.1007/s10551-010-0725-5

Tywoniak, S. A. (2007). Knowledge in four deformation dimensions. Organization. https://doi.org/10.1177/1350508407071860

Valmohammadi, C., \& Ahmadi, M. (2015). The impact of knowledge management practices on organizational performance: A balanced scorecard approach. Journal of Enterprise Information Management, 28(1), 131-159. https://doi.org/10.1108/JEIM-09-2013-0066

van Donk, D. P., \& Riezebos, J. (2005). Exploring the knowledge inventory in project-based organisations: A case study. International Journal of Project Management, 23(1), 75-83. https://doi.org/10.1016/j.ijproman.2004.05.002

Von Krogh, G. (2002). The communal resource and information systems. Journal of Strategic Information Systems, 11(2), 85-107. https://doi.org/10.1016/S0963-8687(02)00006-9

Wang, S., \& Noe, R. A. (2010). Knowledge sharing: A review and directions for future research. Human Resource Management Review, 20(2), 115-131. https://doi.org/10.1016/j.hrmr.2009.10.001

Wang, Z., Sharma, P. N., \& Cao, J. (2016). From knowledge sharing to firm performance: A predictive model comparison. Journal of Business Research, 69(10), 4650-4658. https://doi.org/10.1016/j.jbusres.2016.03.055

Wang, Z., \& Wang, N. (2012). Knowledge sharing, innovation and firm performance. Expert Systems with Applications, 39(10), 8899-8908. https://doi.org/10.1016/j.eswa.2012.02.017

Yeong, A., \& Lim, T. T. (2011). Integrating knowledge management with project management for project success. Journal of Project, Program \& Portfolio Management, 1(2), 8. https://doi.org/10.5130/pppm.v1i2.1735

Yusof, M. N., \& Bakar, A. H. A. (2012). Knowledge Management and Growth Performance in Construction Companies: A Framework. Procedia - Social and Behavioral Sciences, 62, 128-134. https://doi.org/10.1016/j.sbspro.2012.09.022 